\title{
Disappearance Rate of Endogenous Human C-Peptide from Blood
}

\author{
T. Kuzuya and A. Matsuda \\ Department of Medicine, Jichi Medical School, Tochigi-ken, Japan
}

Summary. Glucagon $(1 \mathrm{mg})$ and glucose $(60 \mathrm{ml}$ of $50 \%$ solution) were infused over $60 \mathrm{~min}$ to three normal and one obese subjects and two insulinoma patients. Plasma C-peptide immunoreactivity (CPR) and immunoreactive insulin (IRI) increased during the infusion. Half time of CPR after cessation of the infusion was $20.1 \pm 4.0 \mathrm{~min}$, and that of IRI $9.8 \pm 1.3$ min, respectively. This difference partly explains the higher molar concentration in plasma of CPR than IRI.

Key words: Glucagon-glucose infusion test, synthetic human C-peptide, C-peptide immunoreactivity (CPR), half time for CPR, half time for IRI, insulinoma.

An immunoassay method of connecting peptide (Cpeptide) immunoreactivity (CPR) in blood utilizing synthetic human $\mathrm{C}$-peptide as the standard gave fasting normal CPR levels in the range of $2-2.5 \mathrm{ng} / \mathrm{ml}$ [1]. Despite the evidence of equimolar secretion of C-peptide and insulin from the B-cells [2], the molar ratio of CPR to that of insulin in blood is greater than expected. Heding and Rasmussen [3] and Horwitz et al. [4] also reported higher molar concentrations of CPR than insulin in blood. The most probable explanation is that C-peptide may be degraded much more slowly than insulin in vivo, and thereby reaching a higher steady state blood levels. C-peptide is degraded more slowly than insulin in the rat [5]. In man, the longer half-time of CPR than that of insulin was demonstrated by intravenous injection of synthetic human C-peptide [6] and by measurement of CPR and insulin after the resection of insulinoma [7]. However, the degradation rate of an endogenously secreted human $\mathrm{C}$-peptide in more physiological situations has not been reported. In this study we compared the disappearance rates of endogenous insulin and CPR by means of continuous infusion of glucose and glucagon, followed by sudden cessation of the infusion.

\section{Materials and Methods}

Three normal subjects, one obese patient and two insulinoma patients were studied by a glucagon-glucose infusion test. After an overnight fast, the subject lay in a supine position and both antecubital veins were cannulated; one cannula was used for blood sampling and the other for infusion. Blood coagulation within the needle was prevented by filling with $10 \% \mathrm{Na}$ citrate. One mg glucagon was dissolved in $60 \mathrm{ml}$ of $50 \%$ glucose solution and infused at a rate of $1 \mathrm{ml} / \mathrm{min}$ for $60 \mathrm{~min}$. Blood was taken before, during and after cessation of infusion at timed intervals as described in Figure 1.

Plasma glucose was determined by a glucose oxidase method using Glucostat (Worthington). The Cpeptide radioimmunoassay method is a double-antibody method using synthetic human C-peptide as the standard [1]. This synthetic human C-peptide contains Arg-Arg in the N-terminal and Lys-Arg in the C-terminal in addition to the natural C-peptide liberated from B-cells; its molecular weight is 3600 . Immunoreactive insulin (IRI) was also assayed by a double-antibody method [8] using human monocomponent insulin (Novo) as the standard.

The portal vein blood was withdrawn under direct vision during the surgical operation on an insulinoma patient.

\section{Results}

Plasma glucose, CPR and IRI all increased markedly during infusion of the glucagon and glucose solution. 


\section{Plasma glucose (mg/100ml)}

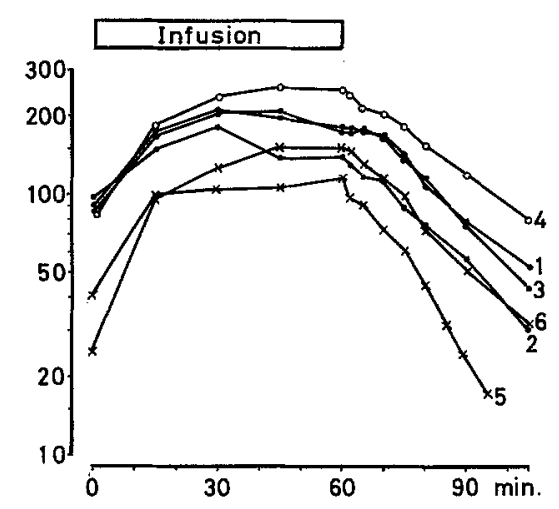

CPR

(ng/ml)

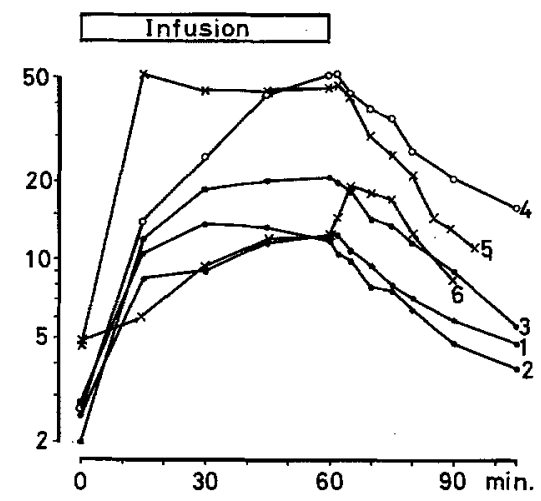

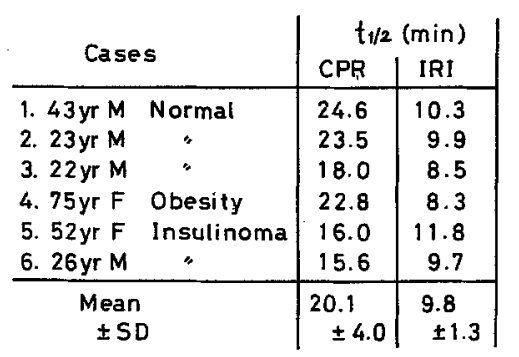

IR I

$(\mu \mathrm{U} / \mathrm{ml})$

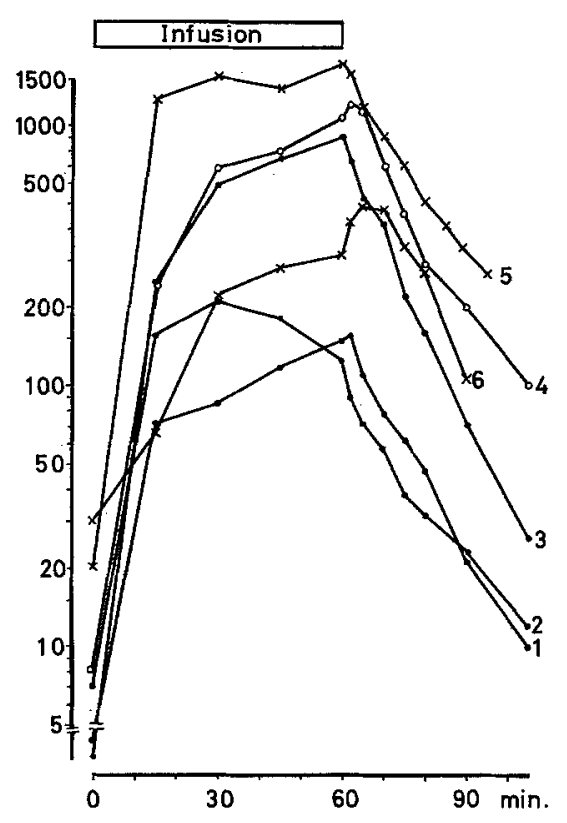

Fig. 1. Changes in plasma CPR, IRI and glucose concentrations during and after 60 -minute infusion of glucagon ( $1 \mathrm{mg})$ and glucose $(60 \mathrm{ml}$ of $50 \%$ solution), and the half lives of CPR and IRI in blood.Semilogarithmic plot is used. Each number at the right of the curve represents each case

At the end of the 60-minute infusion period, plasma glucose had already reached a maximum or even begun to decrease slightly, but CPR and IRI levels were still increasing slowly in some cases. After cessation of the infusion, plasma glucose, CPR and IRI began to decrease immediately or after a short interval. They decreased nearly exponentially. The mean half lives, calculated from the initial linear portion on the semilogarithmic plot, were $20.1 \pm 4.0 \mathrm{~min}$ for CPR and $9.8 \pm 1.3 \mathrm{~min}$ for IRI, respectively. In an insulinoma patient (case 6), CPR and IRI levels increased temporarily after the infusion, and then began to fall. In this patient, the half lives were calculated from the steepest portions on the semilogarithmic plot. Although the maximal CPR and IRI levels were variable between individuals, their half lives were similar.

Two insulinoma patients had slightly shorter half lives than the others, but the significance of this difference is not clear since the number is too small. The portal vein blood of one insulinoma patient (case 5) taken during surgery under glucose infusion contained $8.9 \mathrm{ng} / \mathrm{ml}$ CPR and $320 \mu \mathrm{U} / \mathrm{ml}$ IRI. The molar ratio of CPR to that of IRI in this sample was 1.16.

\section{Discussion}

Glucagon-glucose infusion tests clearly demonstrated that the disappearance rate of endogenous CPR was significantly slower than that of insulin. This procedure was first employed by Samols and Marks [9] to assess the degradation rate of endogenous insulin, but they used a greater amount of glucose and glucagon and a longer period of infusion. The half time of insulin obtained by our procedure, $9.8 \pm 1.3 \mathrm{~min}$, was similar to their data of $7-15$ min. Most other data concerning the half-life of insulin in the blood were obtained by the injection of animal or human insulin, giving a range of 3.3-15 $\mathrm{min}$ [10-13]. The half-time of CPR in our data was $20.1 \pm 4.0 \mathrm{~min}$, which was about twice as long as that of IRI. According to Munemura et al. [6] insulin and synthetic human C-peptide, injected intravenously, had half lives of $3.4 \mathrm{~min}$ and 13 min, respectively. The half-time of CPR and that of insulin after the resection of insulinoma were 11.1 and $4.8 \mathrm{~min}$, as reported by Horwitz et al. [7]. As all the persons tested had hyperglycaemia at the end of the infusion, it is possible that the secretion of C-peptide 
and insulin continued for some time after the termination of the infusion, so that our estimates of half lives could be longer than was really the case.

If $C$-peptide and insulin are secreted at equimolar rates and assuming that the fractional disappearance rates of CPR and IRI $(3.4 \% / \mathrm{min}$ for CPR and $6.8 \%$ for IRI) calculated from the above data are applicable also to a steady state, basal blood CPR concentration would be twice that of insulin. However, the actual assay data indicate an even greater difference in molar concentrations. Molar ratio of CPR to IRI in blood is higher fasting than after glucose stimulation [1, 3, 4]. The greater proportion of proinsulin and related substances in non-stimulated blood samples might contribute to this greater deviation of CPR/IRI molar ratio from unity in basal conditions by their difference in cross-reactivity with C-peptide and insulin immunoassay systems. The liver is the important site of removal of insulin immediately after its secretion from the pancreas, but C-peptide may not be as actively removed by the liver [4]. The kidney may be the principal site of C-peptide degradation [5]. This difference in distribution of the sites of metabolism may also partly account for the higher molar CPR concentration. Despite the difficulty in testing the thesis of equimolar secretion of C-peptide and insulin in man in vivo, it is expected that CPR/IRI ratio would approach unity in blood samples in which the effect of degradation is minimized. Our assay data from the portal vein sample before the resection of insulinoma seem to provide such an example.

Acknowledgements. We are grateful to Daiichi Radioisotope Laboratories for supplying us with Cpeptide assay kit, and to Dr. Schlichtkrull for the gift of standard human monocomponent insulin. Thanks are due to Prof. S. Yoshida for his critical reading of the manuscript and to Miss T. Kawanago for valuable technical assistance.

\section{References}

1. Kuzuya, T., Matsuda, A., Saito, T., Yoshida, S.: Human C-peptide immunoreactivity (CPR) in blood and urine - Evaluation of a radioimmunoassay method and its clinical applications. Diabetologia 12, 511-518 (1976)

2. Rubenstein, A. H., Clark, J. L., Melani, F., Steiner, D. F.: Secretion of proinsulin C-peptide by pancreatic B-cells and its circulation in blood. Nature (Lond.) 224, 697-699 (1969)

3. Heding, L. G., and Rasmussen, S. M.: Human C-peptide in normal and diabetic subjects. Diabetologia 11, 201-206 (1975)

4. Horwitz, D. L., Starr, J. I., Mako, M. E., Blackard, W. G., Rubenstein, A. H.: Proinsulin, insulin and C-peptide concentrations in human portal and peripheral blood. J. clin. Invest. 55, 1278-1283 (1975)

5. Katz, A. I., Rubenstein, A. H.: Metabolism of proinsulin, insulin and C-peptide in the rat. J. clin. Invest. 52, 1113-1121 (1973)

6. Munemura, M., Kaneko, T., Oka, H., Yamashita, K., Suzuki, S., Oda, T., Yanaihara, N., Yanaihara, C.: Disappearance from blood of synthetic human C-peptide (in Japanese). Folia endocr. jap. 50, 1410 (1974)

7. Horwitz, D. L., Starr, J. I., Rubenstein, A. H., Steiner, D. F.: Serum connecting peptide - An indicator of beta cell secretory function. Diabetes 22 (Suppl. 1), 298 (1973)

8. Kanazawa, Y., Kuzuya, T., Ide, T., Kosaka, K.: Plasma insulin responses to glucose in femoral, hepatic and pancreatic veins in dogs. Amer. J. Physiol. 211, 442-448 (1966)

9. Samols, E., Marks, V.: Disappearance rate of endogenous insulin in man. Lancet 1966 II, 700

10. Ørskov, H., Christensen, N. J.: Disappearance rate of exogenous human insulin. Lancet 1966 II, 701

11. Martin, F. I. R., Stocks, A. E., Peason, M. J.: Significance of disappearance rate of injected insulin. Lancet 1967 I, 619-620

12. Rasio, E. A., Hampers, C. L., Soeldner, J. S., Cahill, G. F., Jr.: Diffusion of glucose, insulin, inulin, and Evans-blue protein into thoracic duct lymph of man. J. clin. Invest. 46, 903-910 (1967)

13. Stimmler, L.: Disappearance of immunoreactive insulin in normal and adult onset diabetic subjects. Diabetes 16, 652-655 (1967)

Received: January 9, 1976, and in revised form: July 5, 1976

Dr. T. Kuzuya

Jichi Medical School

Minamikawachi-Machi

Tochigi-Ken

Japan 329-04 